\title{
Luteimicrobium album sp. nov., a novel actinobacterium isolated from a lichen collected in Japan, and emended description of the genus Luteimicrobium
}

\author{
Moriyuki Hamada $^{1,2}$, Hideki Yamamura ${ }^{2}$, Chiaki Komukai ${ }^{1}$, Tomohiko Tamura ${ }^{1}$, Ken-ichiro Suzuki ${ }^{1}$ \\ and Masayuki Hayakawa ${ }^{2}$
}

\begin{abstract}
A novel Gram-stain-positive actinobacterium, designated RI148-Li105 ${ }^{\top}$, was isolated from a lichen sample from Rishiri Island, Japan, and its taxonomic position was investigated by a polyphasic approach. 16S rRNA gene sequencing study indicated that strain RI148-Li105 ${ }^{\top}$ was related to the type strain of Luteimicrobium subarcticum, with a similarity of $97.8 \%$. Cells of strain RI148-Li105 ${ }^{\top}$ exhibited a rod-coccus cycle. The diagnostic cell-wall diamino acid of this organism was lysine and the peptidoglycan type was found to be $A 4 \alpha$. The predominant menaquinones were $M K-8\left(\mathrm{H}_{2}\right)$ and $M K-9\left(\mathrm{H}_{2}\right)$, and the major fatty acids were iso- $\mathrm{C}_{16: 0}, \mathrm{C}_{17: 1} \omega 9 \mathrm{c}$ and $\mathrm{C}_{17: 0}$. The DNA G $+\mathrm{C}$ content was $73.6 \mathrm{~mol} \%$. The major phenotypic characteristics of strain RI148-Li105 ${ }^{\top}$ basically corresponded to those of the genus Luteimicrobium excluding the fatty acid composition. These results suggest that strain RI148-Li105而 should be affiliated with the genus Luteimicrobium. Meanwhile, DNA-DNA hybridization and some phenotypic characteristics revealed that the strain differs from $L$. subarcticum. Therefore, strain RI148-Li $105^{\top}$ represents a novel species of the genus Luteimicrobium, for which the name Luteimicrobium album sp. nov. is proposed. The type strain of Luteimicrobium album is RI148-Li105 $\left(=\right.$ NBRC $106348^{\top}=$ DSM $24866^{\top}$ ).
\end{abstract}

The Journal of Antibiotics (2012) 65, 427-431; doi:10.1038/ja.2012.45; published online 6 June 2012

Keywords: actinobacterium; lichen; Luteimicrobium album sp. nov.; polyphasic taxonomy.

\section{INTRODUCTION}

The genus Luteimicrobium was proposed by Hamada et al. ${ }^{1}$ with a single species, Luteimicrobium subarcticum. The type strain of this species was isolated from a soil sample from Rishiri Island, Japan. The cells are Gram-stain-positive, non-motile and non-spore-forming, and exhibit a rod-coccus life cycle. This organism has peptidoglycan type $\mathrm{A} 4 \alpha$ (with lysine as the diagnostic diamino acid). ${ }^{2}$ The predominant menaquinone and the major fatty acid are MK- $8\left(\mathrm{H}_{2}\right)$ and anteiso$\mathrm{C}_{15: 0}$, respectively. The genus Luteimicrobium is a member of the suborder Micrococcineae in the order Actinomycetales, but the family to which the genus Luteimicrobium belongs has not been specified.

Recently, lichens attracted attention as an isolation source of actinobacteria and, in fact, it has been reported that some actinobacteria were isolated from lichen samples and were proposed as novel taxa, namely Actinomycetospora iriomotensis, A. rishiriensis, Frondihabitans cladoniiphilus, Leifsonia lichenia and Nocardioides exalbidus. ${ }^{3-7}$ During the screening of lichen-associated actinobacteria, we isolated a novel actinobacterium (strain RI148-Li105 ${ }^{\mathrm{T}}$ ) from a foliaceous lichen sample collected from Rishiri Island, Hokkaido, Japan. Comparative 16S rRNA gene sequence analysis revealed that the isolate is related to the genus Luteimicrobium. In the current study, we aim to clarify the taxonomic position of strain RI148-Li105 ${ }^{\mathrm{T}}$ by using a polyphasic approach.

\section{METHODS}

Bacterial strains and isolation

A foliaceous lichen growing on a tree was collected from Rishiri Island, Hokkaido, Japan, and was then air dried for 7 days at room temperature. The lichen sample was homogenized with a sterilized mortar and pestle in the presence of sterilized distilled water, and the suspension was spread on humic acid-vitamin (HV) agar $^{8}$ containing nalidixic acid $\left(20 \mathrm{mg}^{-1}\right)$ and cycloheximide $\left(50 \mathrm{mg}^{-1}\right)$, which was then incubated at $30^{\circ} \mathrm{C}$ for 2 weeks. Following the incubation period, strain RI148-Li105 ${ }^{\mathrm{T}}$ was isolated and transferred to a nutrient agar (NA) plate for purification. Yeast extractStarch medium (NBRC medium 266; containing yeast extract $2 \mathrm{~g}$, soluble starch $10 \mathrm{~g}$ in 1.0 liter tap water; agar $15 \mathrm{~g}$, if required; $\mathrm{pH}$ 7.3) was used for general laboratory cultivation, morphological studies and determination of optimal growth parameters. Biomass for chemotaxonomic and molecular systematic studies was obtained by culturing the strain in shake flasks for 5 days at $28^{\circ} \mathrm{C}$ at 100 r.p.m. Luteimicrobium subarcticum NBRC $105647^{\mathrm{T}}(=\mathrm{R} 19$ -

\footnotetext{
${ }^{1}$ NITE Biological Resource Center (NBRC), National Institute of Technology and Evaluation, Kisarazu, Chiba, Japan and ${ }^{2}$ Division of Applied Biological Sciences, Interdisciplinary Graduate School of Medicine and Engineering, University of Yamanashi, Kofu, Yamanashi, Japan

Correspondence: Dr M Hamada, NITE Biological Resource Center (NBRC), National Institute of Technology and Evaluation, 2-5-8 Kazusakamatari, Kisarazu, Chiba 292-0818, Japan. 
$04^{\mathrm{T}}$ ) was used as the reference strain for comparison with the chemotaxonomic, physiological, biochemical and the DNA-DNA hybridization tests.

\section{Morphological, physiological and biochemical tests}

Colony appearance and pigment production were examined after incubation at $28^{\circ} \mathrm{C}$ for 5 days on agar plate of NBRC medium 266. Morphological features were observed with age (up to 7 days) under a light microscope (model BX-51; Olympus, Tokyo, Japan) and a scanning electron microscope (model JSM-6060; JEOL, Tokyo, Japan). Cell motility was determined by observing cells suspended in a saline solution under a light microscope. The temperature range and optimum temperature for growth were determined by incubating the cultures at $5,10,15,20,25,28,37,45$ and $60^{\circ} \mathrm{C}$ on agar plates of NBRC medium 266 after 5 days incubation. Growth at 5 and $10{ }^{\circ} \mathrm{C}$ was evaluated after 14 days incubation. The $\mathrm{pH}$ range and $\mathrm{NaCl}$ tolerance for growth were determined by measuring the turbidity $(610 \mathrm{~nm})$ of $5 \mathrm{ml}$ of the culture medium in test tubes after 1-5 days of incubation at $28^{\circ} \mathrm{C}$. The $\mathrm{pH}$ range and optimum $\mathrm{pH}$ for growth were established by using a liquid NBRC medium 266 adjusted to $\mathrm{pH}$ $4-10$ in $1.0 \mathrm{pH}$ unit intervals. Tolerance to $\mathrm{NaCl}$ was tested using a liquid NBRC medium 266 adjusted to $\mathrm{NaCl}$ concentrations of $1,3,5,7,10$ and $15 \%(\mathrm{w} / \mathrm{v})$. Growth under anaerobic conditions was determined by incubating in an anaerobic chamber with an $\mathrm{O}_{2}$-absorbing and $\mathrm{CO}_{2}$-generating agent (AnaeroPack; Mitsubishi Gas Chemical, Tokyo, Japan). Gram staining was performed using Hucker's modification. ${ }^{9}$ Oxidase activity was determined using cytochrome oxidase paper (Nissui Pharmaceutical, Tokyo, Japan). Catalase activity was determined by production of bubbles after the addition of a drop of $3.0 \% \mathrm{H}_{2} \mathrm{O}_{2}$. Other physiological and biochemical tests were performed using API ZYM, API Coryne, API 20E and API 50CH systems (bioMérieux, Tokyo, Japan) according to the manufacturer's instructions.

\section{S rRNA sequence determination and phylogenetic analysis}

DNA was isolated and purified using a DNeasy Blood and Tissue kit (Qiagen, Tokyo, Japan) according to the manufacturer's instruction. 16S rRNA gene was amplified by PCR using TaKaRa Ex Taq (Takara Bio, Shiga, Japan) with the following pair of primers: 9F ( $5^{\prime}$-GAGTTTGATCCTGGCTCAG- $\left.3^{\prime}\right)$ and $1541 \mathrm{R}$ ( $5^{\prime}$-AAGGAGGTGATCCAGCC- $\left.3^{\prime}\right)$. The amplified $16 \mathrm{~S}$ rRNA gene was subjected to cycle sequencing using a BigDye Terminator v3.1 Cycle Sequencing Kit (Applied Biosystems, Foster City, CA, USA) with the following primers: $9 \mathrm{~F}, 785 \mathrm{~F}$ (5'-GGATTAGATACCCTGGTAGTC-3'), 802R (5'-TACCA GGGTATCTAATCC-3') and 1541R. The products were analyzed using an automated DNA sequencer (model ABI PRISM 3730 Genetic Analyzer; Applied Biosystems). The phylogenetic neighbors were identified and pairwise 16S rRNA gene sequence similarities were calculated using the EzTaxon server. ${ }^{10}$ The almost-complete $16 \mathrm{~S}$ rRNA gene sequence determined in this study was aligned with reference sequences of the genus Luteimicrobium and some related taxa by using the CLUSTAL_X program. ${ }^{11}$ Phylogenetic trees were constructed using the neighbor-joining and maximum-likelihood algorithms ${ }^{12,13}$ using the MEGA 5.0 program. ${ }^{14}$ The resultant tree topologies were evaluated by bootstrap analysis ${ }^{15}$ based on 1000 replicates.

\section{G + C content of DNA and DNA-DNA hybridization}

DNA was obtained using the method of Saito and Miura. ${ }^{16}$ The DNA G $+C$ content was determined by the method of Tamaoka and Komagata ${ }^{17}$ using a high-performance liquid chromatography (model LC-10A; Shimadzu, Kyoto, Japan) equipped with a Cosmosil $5 \mathrm{C}_{18}$-MS-II column $(100 \times 4.6 \mathrm{~mm}$ i.d.; Nacalai Tesque, Kyoto, Japan). Acetonitrile-water containing $0.2 \mathrm{~m}$ ammonium phosphate was used as the mobile phase (acetonitrile, 5\%, $15 \mathrm{~min}$ ) at the flow rate of $1.0 \mathrm{ml} \mathrm{min}^{-1}$ with $\mathrm{UV}$ detection at $270 \mathrm{~nm}$. The microplate hybridization method developed by Ezaki et al. ${ }^{18,19}$ was used to determine DNA relatedness with minor modification. ${ }^{20}$

\section{Chemotaxonomic tests}

Cell-wall samples were prepared from $\sim 1 \mathrm{~g}$ of wet cells by carrying out mechanical disruption with an ultrasonic oscillator. The cell walls were separated from unbroken cells by differential centrifugation in distilled water, and further purified in boiling $4 \% \operatorname{SDS}\left(100^{\circ} \mathrm{C}, 30 \mathrm{~min}\right)$, followed by several washings with distilled water. Molar ratios of the amino acids in cell-wall hydrolysates $\left(4 \mathrm{M} \mathrm{HCl}, 16 \mathrm{~h}\right.$ at $\left.100^{\circ} \mathrm{C}\right)$ were determined by high-performance liquid chromatography (model LC-10AD; Shimadzu) equipped with a Wakopak wakosil-PTC column $(200 \times 2.0 \mathrm{~mm}$ i.d.; Wako Pure Chemical Industries, Osaka, Japan), as their phenyl isothiocyanate derivatives (Wako Pure Chemical Industries). PTC-amino acids mobile phase A-PTC-amino acids mobile phase B (Wako Pure Chemical Industries) was used as the mobile phase under a linear gradient elution mode (solution B, 0-100\%, $20 \mathrm{~min}$ ) at the flow rate of $1.0 \mathrm{ml} \mathrm{min}{ }^{-1}$ with $\mathrm{UV}$ detection at $254 \mathrm{~nm}$. Amino-acid isomers in the cell-wall hydrolysates were analyzed according to the method described by Nozawa et al. ${ }^{21}$ using a liquid chromatograph-mass spectrometer (LC-MS; model LCMS-2020 and LC-20AB; Shimadzu) equipped with a ShimPack FC-ODS column $(150 \times 2.0 \mathrm{~mm}$ i.d.; Shimadzu $)$. Cell-wall sugars were analyzed as 1-phenyl-3-methyl-5-pyrazolone derivatives of the cell-wall hydrolysates $\left(4 \mathrm{M} \mathrm{HCl}, 16 \mathrm{~h}\right.$ at $\left.100^{\circ} \mathrm{C}\right)$, which were prepared according to the method described by Honda et al..$^{22}$ and Yang et al. ${ }^{23}$ The 1-phenyl-3methyl-5-pyrazolone-labeled hydrolysates were analyzed using a LC-MS (model LCMS-2020 and LC-20AB; Shimadzu), equipped with a Shim-Pack FC-ODS column $(150 \times 2.0 \mathrm{~mm}$ i.d.; Shimadzu $)$. Acetonitrile-water containing $5 \mathrm{~mm}$ formic acid was used as the mobile phase under a linear gradient elution mode (acetonitrile, $15-30 \%, 30 \mathrm{~min}$ ) at the flow rate of $0.2 \mathrm{ml} \mathrm{min}^{-1}$ with UV detection at $250 \mathrm{~nm}$. Isoprenoid quinones were extracted from $\sim 300 \mathrm{mg}$ of dry cells by using chloroform-methanol (2:1, v/v). The menaquinone fractions were separated by TLC using hexane-diethyl ether $(8.5: 1.5, \mathrm{v} / \mathrm{v})$ as the solvent. The menaquinone spot was detected under UV light, and the menaquinones were extracted with acetone, dried using a nitrogen stream and then analyzed using a LC-MS (model LCMS-8030 and LC-20AD; Shimadzu) equipped with a Senshu-Pak Pegasil ODS-SP-100 column $(100 \times 2.0 \mathrm{~mm}$ i.d.; Senshu Scientific, Tokyo, Japan $)$. Methanolisopropanol was used as the mobile phase (34\% isopropanol, $60 \mathrm{~min}$ ) at the flow rate of $0.2 \mathrm{ml} \mathrm{min}^{-1}$ with UV detection at $275 \mathrm{~nm}$. The preparation and analysis of cellular fatty acid methyl esters were performed using the protocol of the MIDI Sherlock Microbial Identification System ${ }^{24,25}$ and a gas chromatography (model 6890N; Agilent Technologies, Santa Clara, CA
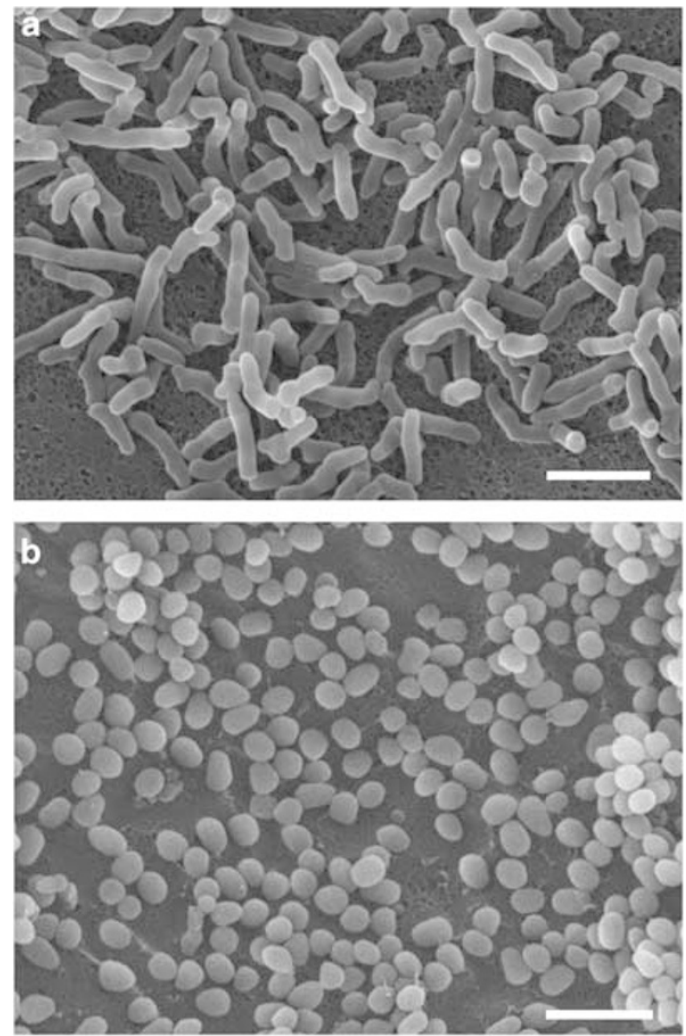

Figure 1 Scanning electron micrographs of strain RI148-Li105 grown on NBRC medium 266 for 1 day (a) and 5 days (b) at $28^{\circ} \mathrm{C}$. Bar, $2 \mu \mathrm{m}$. 
USA). The fatty acids were identified using the Microbial Identification Sherlock software package (ACTINO database, version 4.0). Polar lipid analysis was performed as described by Hamada et al. ${ }^{26}$

\section{Nucleotide sequence accession number}

The GenBank/EMBL/DDBJ accession number for the $16 \mathrm{~S}$ rRNA gene sequence of strain RI148-Li105 ${ }^{\mathrm{T}}$ is AB646194.

\section{RESULTS}

Strain RI148-Li105 ${ }^{\mathrm{T}}$ formed circular, smooth and white colonies that were approximately $0.5 \mathrm{~mm}$ in diameter on NBRC medium 266 after 5 days of incubation at $28^{\circ} \mathrm{C}$. Pigment production was not observed. The cells of the strain were Gram-stain-positive, facultatively anaerobic, non-motile and non-spore-forming and exhibited a rod-coccus life cycle. Cells of exponentially growing cultures were irregular rods $(0.5-0.7 \times 1.5-4.0 \mu \mathrm{m})$, whereas stationary-phase cells were cocci ( $\sim 0.5 \mu \mathrm{m}$ in diameter) (Figure 1 ). Growth occurred at $10-37^{\circ} \mathrm{C}$ and no growth was observed at 5,45 or $60^{\circ} \mathrm{C}$. The $\mathrm{pH}$ range for growth was 6.0-8.0. Optimal growth was noted at $28^{\circ} \mathrm{C}$ and $\mathrm{pH} 7.0$. The strain exhibited good growth with $\mathrm{NaCl}$ concentrations of $0-3 \%$ (w/v) and moderate growth with 5\%; no growth was observed with 7 , 10 or $15 \% \mathrm{NaCl}$. The optimal $\mathrm{NaCl}$ concentration for growth was $1 \%$.
The results of other physiological and biochemical analyses are summarized in the species description below.

Phylogenetic analysis on the basis of the 16S rRNA gene sequence revealed that strain RI148-Li105 ${ }^{\mathrm{T}}$ belonged to the suborder Micrococcineae. However, this strain did not form a reliable clade with any members of the suborder. The highest similarity value was observed with Luteimicrobium subarcticum (97.8\%), followed by Cellulomonas chitinilytica (97.2\%), C. denverensis (97.0\%) and Cellulosimicrobium funkei $(97.0 \%)$. In the neighbor-joining tree, the phylogenetic lineage of strain RI148-Li105 ${ }^{\mathrm{T}}$ joined that of L. subarcticum R19-04 ${ }^{\mathrm{T}}$ (Figure 2). Although the bootstrap value of this branch was low in the neighbor-joining tree, this relationship was also recovered in the tree generated with the maximum-likelihood algorithm. The DNADNA relatedness between strain RI148-Li105 ${ }^{\mathrm{T}}$ and $L$. subarcticum NBRC $105647^{\mathrm{T}}$ (=R19-04 ${ }^{\mathrm{T}}$ ) was $1-9 \%$. These values are well below the $70 \%$ cutoff point of DNA-DNA relatedness, which is a criterion for the assignment of bacterial strains to the same genomic species. ${ }^{27}$

The obtained peptidoglycan sample of strain RI148-Li105 ${ }^{\mathrm{T}}$ contained alanine (Ala), glutamic acid (Glu) and lysine (Lys) in a molar ratio of 2.0:2.0:1.1. Enantiomeric analysis of the peptidoglycan amino acids revealed the presence of D-Ala, L-Ala, D-Glu and L-Lys. These data strongly suggested that the cell-wall peptidoglycan of strain

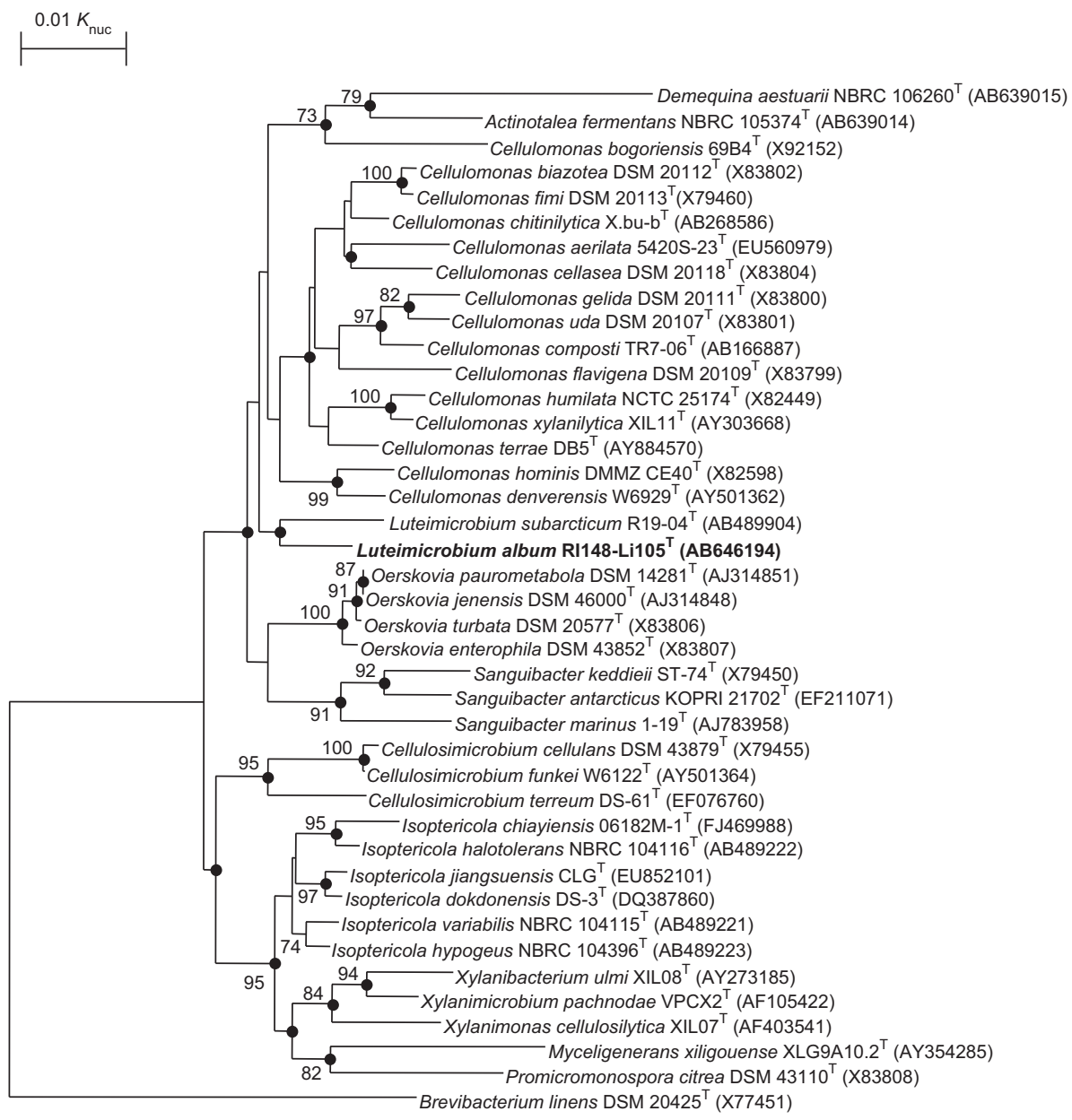

Figure 2 Phylogenetic tree derived from the 16S rRNA gene sequences of strain RI148-Li105 ${ }^{\top}$ and its taxonomic neighbors. The tree was constructed using the neighbor-joining method. The 16S rRNA gene sequence of Brevibacterium linens DSM $20425^{\top}$ (X77451) was used as the out-group. The numbers at the branch nodes are bootstrap percentages (from 1000 replicates); only values of $70 \%$ or above are shown. Dots indicate that the corresponding nodes were also recovered in the tree generated with the maximum-likelihood algorithm. Bar, $0.01 K_{\text {nuc }}$. 
RI148-Li105 ${ }^{\mathrm{T}}$ was of A4 $\alpha$ type as described by Schleifer \& Kandler, ${ }^{2}$ with L-Lys as the diagnostic cell-wall diamino acid and an interpeptide bridge of the peptidoglycan comprising D-Glu. The major cell-wall sugar was mannose, whereas galactose was a trace component. The predominant menaquinones were MK- $8\left(\mathrm{H}_{2}\right)$ and MK-9 $\left(\mathrm{H}_{2}\right)$ (65:35). The major cellular fatty acids were iso- $\mathrm{C}_{16: 0}(42.7 \%), \mathrm{C}_{17: 1} \omega 9 \mathrm{c}$ $(23.4 \%)$ and $\mathrm{C}_{17: 0}(12.2 \%)$ (Table 1$)$. The major polar lipids determined were diphosphatidylglycerol, phosphatidylinositolmannoside, one glycolipid and four unidentified polar lipids, along with minor or trace amounts of phosphatydylinositol and one additional unidentified polar lipid (Supplementary Figure 1). The DNA G $+\mathrm{C}$ content was $73.6 \mathrm{~mol} \%$.

\section{DISCUSSION}

Phylogenetic analysis based on 16S rRNA gene sequence suggested that strain RI148-Li105 ${ }^{\mathrm{T}}$ was phylogenetically related to the member of the genus Luteimicrobium. In addition, strain RI148-Li105 ${ }^{\mathrm{T}}$ exhibited a rod-coccus life cycle, and the peptidoglycan of the strain was of $A 4 \alpha$ type. These phenotypic characteristics corresponded to those of the genus Luteimicrobium. The predominant menaquinones

Table 1 Cellular fatty acid compositions (\%) of strain RI148-Li105' and $L$. subarcticum NBRC $105647^{\top}$

\begin{tabular}{|c|c|c|}
\hline Fatty acid & $R / 148-L i 105^{T}$ & L. subarcticum NBRC $105647^{T}$ \\
\hline \multicolumn{3}{|c|}{ Straight-chain saturated fatty acids } \\
\hline$C_{14: 0}$ & - & 1.3 \\
\hline $\mathrm{C}_{15: 0}$ & 2.4 & - \\
\hline $\mathrm{C}_{16: 0}$ & 3.0 & 10.9 \\
\hline $\mathrm{C}_{17: 0}$ & 12.2 & - \\
\hline \multicolumn{3}{|c|}{ Branched saturated fatty acids } \\
\hline iso- $\mathrm{C}_{14: 0}$ & 1.1 & 1.0 \\
\hline iso- $\mathrm{C}_{15: 0}$ & - & 2.3 \\
\hline iso- $\mathrm{C}_{16: 0}$ & 42.7 & 5.1 \\
\hline iso- $\mathrm{C}_{18: 0}$ & 1.4 & - \\
\hline anteiso- $\mathrm{C}_{15: 0}$ & - & 71.4 \\
\hline anteiso- $\mathrm{C}_{17: 0}$ & - & 8.0 \\
\hline \multicolumn{3}{|c|}{ Mono-unsaturated fatty acids } \\
\hline $\mathrm{C}_{16: 1} \omega 9 \mathrm{c}$ & 2.5 & - \\
\hline $\mathrm{C}_{17: 1} \omega 9 \mathrm{c}$ & 23.4 & - \\
\hline $\mathrm{C}_{18: 1} \omega 9 \mathrm{c}$ & 5.2 & - \\
\hline \multicolumn{3}{|c|}{ 10-Methyl fatty acids } \\
\hline 10-Methyl $C_{17: 0}$ & 4.4 & - \\
\hline
\end{tabular}

Bold type shows the major components ( $>10 \%)$. -, Not detected or detected in trace amounts $(<1 \%)$. of the strain were MK- $8\left(\mathrm{H}_{2}\right)$ and MK-9 $\left(\mathrm{H}_{2}\right)$ (molar ratio, 65: 35), and that of L. subarcticum was MK-8 $\left(\mathrm{H}_{2}\right)$ with $\mathrm{MK}-9\left(\mathrm{H}_{2}\right)$ as the minor component (molar ratio, 90:10). Therefore, it can be considered that strain RI148-Li105 ${ }^{\mathrm{T}}$ and L. subarcticum have a similar isoprenoid quinone system. This characteristic permits the distinction among the genus Luteimicrobium and its phylogenetic neighbors (Table 2). Considering the result of the phylogenetic analysis, the menaquinone composition and the peptidoglycan structure, it is suitable that strain RI148-Li105 ${ }^{\mathrm{T}}$ is regarded as a member of the genus Luteimicrobium. The major fatty acid of Luteimicrobium subarcticum and the members of the genera Cellulomonas, Cellulosimicrobium, Isoptericola and Oerskovia was reported to be anteiso- $\mathrm{C}_{15: 0}$. Meanwhile, the major fatty acid of strain RI148-Li105 ${ }^{\mathrm{T}}$ was iso- $\mathrm{C}_{16: 0}$, but anteiso-branched fatty acids were not detected (Table 2). Also, it is interesting that monounsaturated fatty acid $\left(\mathrm{C}_{17: 1} \omega 9 \mathrm{c}\right)$ was detected as the major component of strain RI148-Li105 ${ }^{\mathrm{T}}$. At this time, the difference of cellular fatty acid profile may be considered as a interspecies diversity within the genus Luteimicrobium as well. If many strains closely related to the genus Luteimicrobium are discovered in the future, strain RI148-Li105 ${ }^{\mathrm{T}}$ may be reclassified in a separate genus.

On the other hand, the DNA-DNA relatedness between strain RI148-Li105 ${ }^{\mathrm{T}}$ and L. subarcticum was low, and the results of the physiological and biochemical tests distinguished strain RI148-Li105 ${ }^{\mathrm{T}}$ from L. subarcticum (Table 3). Therefore, a novel species of the genus Luteimicrobium, namely, Luteimicrobium album sp. nov., is proposed for strain RI148-Li105 ${ }^{\mathrm{T}}$. In addition, the description of the genus Luteimicrobium Hamada et al. ${ }^{1}$ should be emended to reflect the variations in the fatty acid profile, menaquinone composition, polar lipids and oxygen relationship.

\section{Emended description of the genus Luteimicrobium}

The description is as given by Hamada et al. ${ }^{1}$ with the following modifications. Cells are aerobic or facultatively anaerobic. The predominant menaquinones are MK- $8\left(\mathrm{H}_{2}\right)$ and/or MK-9 $\left(\mathrm{H}_{2}\right)$. The major cellular fatty acids consist of iso- or anteiso- branched fatty acids. Straight-chain and monounsaturated fatty acids may be contained as major components. The major polar lipid is diphosphatidylglycerol. Phosphatidylglycerol, phsphatidylinositolmannoside and glycolipid may be contained as the major components.

\section{Description of Luteimicrobium album sp. nov.}

Luteimicrobium album (al'bum. L. neut. adj. album, white). Cells exhibit a rod-coccus cycle and are Gram-stain-positive, facultatively anaerobic, non-motile and non-spore-forming. Rods are $0.5-0.7 \times$ $1.5-4.0 \mu \mathrm{m}$ and cocci are $\sim 0.5 \mu \mathrm{m}$ in diameter. Colonies are circular, smooth and white. Catalase- and oxidase-negative. The temperature range for growth is $10-37^{\circ} \mathrm{C}$, and the optimal temperature is $28^{\circ} \mathrm{C}$. The

Table 2 Major chemotaxonomic characteristics of strain RI148-Li105 ${ }^{\top}$ and the genera Luteimicrobium, Cellulomonas, Cellulosimicrobium, Isoptericola and Oerskovia

\begin{tabular}{|c|c|c|c|c|c|c|}
\hline Characteristic & 1 & 2 & 3 & 4 & 5 & 6 \\
\hline Peptidoglycan type & $\mathrm{A} 4 \alpha$ & $\mathrm{A} 4 \alpha$ & $A 4 \beta$ & $\mathrm{A} 4 \alpha$ & $A 4 \alpha$ & $\mathrm{A} 4 \alpha$ \\
\hline Diamino acid & L-Lys & L-Lys & L-Orn & L-Lys & L-Lys & L-Lys \\
\hline Interpeptide bridge & D-Glu & D-Glu & D-Asp or D-Glu & D-Ser-D-Asp or L-Thr-L-Asp & D-Asp or D-Glu & L-Thr-D-Asp or L-Thr-D-Glu \\
\hline Major menaquinone(s) & MK-8 $\left(\mathrm{H}_{2}\right), \mathrm{MK}-9\left(\mathrm{H}_{2}\right)$ & $\mathrm{MK}-8\left(\mathrm{H}_{2}\right)$ & MK-9 $\left(\mathrm{H}_{4}\right), \mathrm{MK}-8\left(\mathrm{H}_{4}\right)$ & $\mathrm{MK}-9\left(\mathrm{H}_{4}\right)$ & MK-9 $\left(\mathrm{H}_{4}\right)$ & MK-9(H $\left(\mathrm{H}_{4}\right)$ \\
\hline Major fatty acids & $\mathrm{i}-\mathrm{C}_{16: 0}, \mathrm{C}_{17: 1} \omega 9 \mathrm{c}, \mathrm{C}_{17: 0}$ & ai- $C_{15: 0}, C_{16: 0}$ & ai- $C_{15: 0}, C_{14: 0}$ & ai- $C_{15: 0}, \mathrm{i}-\mathrm{C}_{15: 0}$ & ai- $C_{15: 0}, \mathrm{i}-\mathrm{C}_{15: 0}$ & ai- $C_{15: 0}, C_{16: 0}$ \\
\hline
\end{tabular}

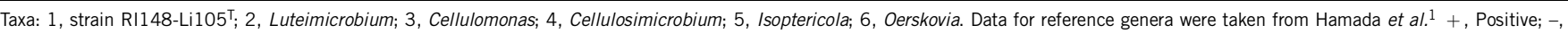
negative; ai, anteiso-branched; i, iso-branched. 
Table 3 Differential phenotypic characteristics of strain RI148-Li105 ${ }^{\top}$ and Luteimicrobium subarcticum

\begin{tabular}{|c|c|c|}
\hline Characteristic & R/148-Li105' & L. subarcticum \\
\hline Colony color & White & Yellow \\
\hline Growth at $37^{\circ} \mathrm{C}$ & + & - \\
\hline $\mathrm{pH}$ range for growth & $6.0-8.0$ & $5.0-9.0$ \\
\hline Catalase & - & + \\
\hline Acid phosphatase & + & - \\
\hline$\beta$-Galactosidase & - & + \\
\hline$\alpha$-Glucosidase & - & + \\
\hline Nitrate reduction & - & + \\
\hline \multicolumn{3}{|c|}{ Acid production from (API 50CH): } \\
\hline$N$-acetyl-glucosamine & - & + \\
\hline Amygdalin & - & + \\
\hline L-arabinose & - & + \\
\hline Arbutin & - & + \\
\hline Gentiobiose & - & + \\
\hline Salicin & - & + \\
\hline D-turanose & + & - \\
\hline Major fatty acids (>10\%) & $\mathrm{i}-\mathrm{C}_{16: 0}, \mathrm{C}_{17: 1} \omega 9 \mathrm{c}, \mathrm{C}_{17: 0}$ & ai- $C_{15: 0}, C_{16: 0}$ \\
\hline Polar lipids & DPG, PI, PIM, GL & DPG, PG \\
\hline DNA G $+C$ content (mol\%) & 73.6 & 72.9 \\
\hline
\end{tabular}

Abbreviations: +, positive; -, negative; ai, anteiso-branched; i, iso-branched; DPG diphosphatidylglycerol; PG, phosphatidylglycerol; PI, phosphatidylinositol; PIM, phosphatidylinositolmannoside; GL, glycolipid.

$\mathrm{pH}$ range for growth is 6.0-8.0, and the optimal $\mathrm{pH}$ is 7.0. Growth occurs at $\mathrm{NaCl}$ concentrations of $0-5 \%(\mathrm{w} / \mathrm{v})$, but not at concentrations higher than $7 \%$. The optimal $\mathrm{NaCl}$ concentration for growth is $1 \%$. Acid is produced from D-cellobiose, D-fructose, D-galactose, D-glucose, D-maltose, D-mannose, D-sucrose and D-xylose. $N$-acetyl- $\beta$-glucosaminidase, acid phosphatase, $\beta$-glucosidase, leucine arylamidase are present, whereas alkaline phosphatase, arginine dihydrolase, $\alpha$-chymotrypsin, cysteine arylamidase, esterase (C4), esterase lipase (C8), $\alpha$-fucosidase, $\alpha$-galactosidase, $\beta$-galactosidase, $\alpha$-glucosidase, $\beta$-glucuronidase, lipase (C14), lysine decarboxylase, $\alpha$-mannosidase, ornithine decarboxylase, phosphohydrolase, pyrazinamidase, trypsin, tryptophan deaminase, urease and valine arylamidase are absent. Aesculin is hydrolyzed, but gelatin is not. $\mathrm{H}_{2} \mathrm{~S}$ and indole are not produced. Nitrate is not reduced. The peptidoglycan is of the A4 $\alpha$ type with an interpeptide bridge comprising D-Glu. The major cell-wall sugar is mannose. The predominant menaquinones are MK- $8\left(\mathrm{H}_{2}\right)$ and MK- $9\left(\mathrm{H}_{2}\right)$. The major cellular fatty acids are iso- $\mathrm{C}_{16: 0}, \mathrm{C}_{17: 1} \omega 9 \mathrm{c}$ and $\mathrm{C}_{17: 0}$, followed by $\mathrm{C}_{18: 1} \omega 9 \mathrm{c}, 10$-methyl $\mathrm{C}_{17: 0}, \mathrm{C}_{16: 0}, \mathrm{C}_{16: 1} \omega 9 \mathrm{c}, \mathrm{C}_{15: 0}$, iso$\mathrm{C}_{18: 0}$, iso- $\mathrm{C}_{18: 0}$ and $\mathrm{C}_{18: 0}$. The polar lipids are diphosphatidylglycerol, phosphatidylinositolmannoside, one glycolipid and four unidentified polar lipids. The DNA G $+\mathrm{C}$ content of the type strain is $73.6 \mathrm{~mol} \%$.

The type strain RI148-Li105 ${ }^{\mathrm{T}}\left(=\mathrm{NBRC} 106348^{\mathrm{T}}=\mathrm{DSM} 24866^{\mathrm{T}}\right.$ ) was isolated from a lichen sample from Rishiri Island, Japan.

\section{ACKNOWLEDGEMENTS}

We are grateful to Mr Yuya Sakuraki for excellent technical assistance. This study was partly supported by a research grant from the Institute for Fermentation, Osaka (IFO), Japan.
1 Hamada, M. et al. Luteimicrobium subarcticum gen. nov., sp. nov., a new member of the suborder Micrococcineae. Int. J. Syst. Evol. Microbiol. 60, 796-800 (2010).

2 Schleifer, K. H. \& Kandler, O. Peptidoglycan types of bacterial cell walls and their taxonomic implications. Bacteriol. Rev. 36, 407-477 (1972).

3 Yamamura, $\mathrm{H}$. et al. Actinomycetospora iriomotensis sp. nov., a novel actinomycete isolated from a lichen sample. J. Antibiot. 64, 289-292 (2011).

4 Yamamura, H. et al. Actinomycetospora rishiriensis sp. nov., an actinomycete isolated from a lichen. Int. J. Syst. Evol. Microbiol. 61, 2621-2625 (2011).

5 Cardinale, M., Grube, M. \& Berg, G. Frondihabitans cladoniiphilus sp. nov., a novel actinobacterium of the family Microbacteriaceae isolated from lichen, and emended description of the genus Frondihabitans. Int. J. Syst. Evol. Microbiol. 61, 3033-3038 (2011).

6 An, S. Y., Xiao, T. \& Yokota, A. Leifsonia lichenia sp. nov., isolated from lichen in Japan. J. Gen. Appl. Microbiol. 55, 339-343 (2009).

7 Li, B., Xie, C. H. \& Yokota, A. Nocardioides exalbidus sp. nov., a novel actinomycete isolated from lichen in Izu-Oshima Island, Japan. Actinomycetologica 21, 22-26 (2007).

8 Hayakawa, M. \& Nonomura, H. Humic acid-vitamin agar, a new medium for the selective isolation of soil actinomycetes. J. Ferment. Technol. 65, 501-509 (1987).

9 Gerhardt, P., Murray, R. G. E., Wood, W. A. \& Krieg, N. R. Methods for General and Molecular Bacteriology (Edited by American Society for Microbiology) (Washington, DC, 1994).

10 Chun, J. et al. EzTaxon: a web-based tool for the identification of prokaryotes based on $16 \mathrm{~S}$ ribosomal RNA gene sequences. Int. J. Syst. Evol. Microbiol. 57, 2259-2261 (2007).

11 Thompson, J. D., Gibson, T. J., Plewniak, F., Jeanmougin, F. \& Higgins, D. G. The CLUSTAL_X windows interface: flexible strategies for multiple sequence alignment aided by quality analysis tools. Nucleic Acids Res. 25, 4876-4882 (1997).

12 Saitou, N. \& Nei, M. The neighbor-joining method: a new method for reconstructing phylogenetic trees. Mol. Biol. Evol. 4, 406-425 (1987).

13 Felsenstein, J. Evolutionary trees from DNA sequences: a maximum likelihood approach. J. Mol. Evol. 17, 368-376 (1981).

14 Tamura, K. et al. MEGA5: molecular evolutionary genetics analysis using maximum likelihood, evolutionary distance, and maximum parsimony methods. Mol. Biol. Evol. 28, 2731-2739 (2011).

15 Felsenstein, J. Confidence limits on phylogenies: an approach using the bootstrap. Evolution 39, 738-791 (1985).

16 Saito, H. \& Miura, K. Preparation of transforming deoxyribonucleic acid by phenol treatment. Biochim. Biophys. Acta. 72, 619-629 (1963).

17 Tamaoka, J. \& Komagata, K. Determination of DNA base composition by reversedphase high-performance liquid chromatography. FEMS. Microbiol. Lett. 25, 125-128 (1984).

18 Ezaki, T. et al. Simple genetic identification method of viridans group streptococci by colorimetric dot hybridization and quantitative fluorometric hybridization in microdilution wells. J. Clin. Microbiol. 26, 1708-1713 (1988).

19 Ezaki, T., Hashimoto, Y. \& Yabuuchi, E. Fluorometric deoxyribonucleic aciddeoxyribonucleic acid hybridization in microdilution wells as an alternative to membrane filter hybridization in which radioisotopes are used to determine genetic relatedness among bacterial strains. Int. J. Syst. Bacteriol. 39, 224-229 (1989).

20 Tamura, T., Nakagawa, Y. \& Kawasaki, H. DNA-DNA hybridization method. In Identification Manual of Actinomycetes (Edited by The Society for Actinomycetes Japan) 134-137 (The Business Center for Academic Societies in Japanese, Tokyo, 2001).

21 Nozawa, Y., Sakai, N., Arai, K., Kawasaki, Y. \& Harada, K. Reliable and sensitive analysis of amino acids in the peptidoglycan of actinomycetes using the advanced Marfey's method. J. Microbiol. Methods 70, 306-311 (2007).

22 Honda, S. et al. High-performance liquid chromatography of reducing carbohydrates as strongly ultraviolet-absorbing and electrochemically sensitive 1-phenyl-3-methyl-5pyrazolone derivatives. Anal. Biochem. 180, 351-357 (1989).

23 Yang, X., Zhao, Y., Wang, Q., Wang, H. \& Mei, Q. Analysis of the monosaccharide components in Angelica polysaccharides by high performance liquid chromatography. Anal. Sci. 21, 1177-1180 (2005)

24 Sasser, M. Identification of Bacteria by Gas Chromatography of Cellular Fatty Acids, MIDI Technical Note 101. MIDI Inc. Newark, Delaware (1990).

25 MIDI MIS operating manual, version 4.5. MIDI, Inc. Newark, Delaware (2002)

26 Hamada, M. et al. Mobilicoccus pelagius gen. nov., sp. nov. and Piscicoccus intestinalis gen. nov., sp. nov., two new members of the family Dermatophilaceae, and reclassification of Dermatophilus chelonae (Masters et al. 1995) as Austwickia chelonae gen. nov., comb. nov. J. Gen. Appl. Microbiol. 56, 427-436 (2010).

27 Wayne, L. G. et al. Report of the ad hoc committee on reconciliation of approaches to bacterial systematics. Int. J. Syst. Bacteriol. 37, 463-464 (1987).

Supplementary Information accompanies the paper on The Journal of Antibiotics website (http://www.nature.com/ja) 